\title{
Growth, production and nutrients in coriander cultivated with biofertilizer
}

\author{
Marinice O Cardoso' ${ }^{1}$; Rodrigo F Berni ${ }^{1}$; Isaac C Antonio ${ }^{1}$; Cristiaini Kano²
}

'Embrapa Amazônia Ocidental, Manaus-AM, Brasil; marinice.cardoso@embrapa.br; rodrigo.berni@embrapa.br; isaac.cohen@embrapa. br; ${ }^{2}$ Embrapa Monitoramento por Satélite, Campinas-SP, Brasil; cristiaini.kano@embrapa.br

\begin{abstract}
The aim of this study was to evaluate the effect of doses of a biofertilizer, formulated with a mix of plants (BMV), on the growth, production and nutrients in coriander cultivar Verdão. The BMV was prepared with crushed parts of the species Flemingia macrophylla, Musa sp. and Azolla sp. The trial was carried out in a greenhouse, in Yellow Argissol, with medium texture $(\mathrm{V}=36.4 \%)$. The experimental design was of randomized blocks with six replicates. Besides BMV doses $(0,5,10,15$ and $30 \%$, in water), an additional treatment with bovine manure biofertilizer was added (10\% in water). Inorganic ingredients blended into biofertilizers as chicken manure were incorporated in soil of growing-beds. The evaluated traits responded to BMV doses linearly. A decrease in green mass (GM) of plants, from 1.43 to $0.88 \mathrm{~kg} / \mathrm{m}^{2}$, which is the commercial product, and plant height, from 31.33 to $24.02 \mathrm{~cm}$, was attributed to the astringency of Musa sp. in the biofertilizer, together with $\mathrm{N}$ shortage. The plant aerial part dry mass (DM) increased from 11.29 to $13.75 \mathrm{~g} / 100 \mathrm{~g}$ due to fibrous stems under nitrogen deficiency. Nutrient contents increased ( $\mathrm{B}$ and $\mathrm{Zn})$, did not range $(\mathrm{N}, \mathrm{S}$, and $\mathrm{Cu}$ ) or decreased $(\mathrm{P}, \mathrm{K}, \mathrm{Ca}, \mathrm{Mg}$, $\mathrm{Fe}$ and $\mathrm{Mn}$ ) and accumulation increased $(\mathrm{N}, \mathrm{S}, \mathrm{K}, \mathrm{B}, \mathrm{Zn}$ and $\mathrm{Cu})$, decreased $(\mathrm{Fe})$ or did not change ( $\mathrm{P}, \mathrm{Ca}, \mathrm{Mg}$ and $\mathrm{Mn})$. The analysis of the principal components showed DM and accumulations of $\mathrm{P}, \mathrm{K}$, $\mathrm{Ca}, \mathrm{Mg}$ and $\mathrm{S}$ in the same direction and antagonism of $\mathrm{N}$ with $\mathrm{Ca}$ and $\mathrm{Mg}$, attributed to loss of $\mathrm{N}$ at alkaline $\mathrm{pH}$, by natural phosphate (FN) in BMV. And also, DM, B, Cu and $\mathrm{Zn}$ accumulations increased concomitantly while accumulations of Fe and Mn did not compete. The manure biofertilizer surpassed the BMV in GM (1.38 and 1.21 $\mathrm{kg} / \mathrm{m}^{2}$, respectively), as well as accumulations of $\mathrm{N}$ and $\mathrm{K}$.
\end{abstract}

Keywords: Coriandrum sativum, organic manure, alternative fertilizer.

\section{RESUMO}

Crescimento, produção e nutrientes no coentro cultivado com biofertilizante

Objetivou-se avaliar o efeito de doses de um biofertilizante de materiais vegetais (BMV) sobre o crescimento, produção e nutrientes no coentro 'Verdão'. O BMV foi preparado com partes trituradas das espécies Flemingia macrophylla, Musa sp. e Azolla sp. O ensaio foi conduzido em cultivo protegido, em Argissolo Amarelo textura média $(\mathrm{V} \%=36,4)$. O delineamento experimental foi de blocos ao acaso com seis repetições. Além das doses do BMV (0, 5, 10, 15 e $30 \%$ em água), foi adicionado um tratamento com biofertilizante de esterco bovino (10\% em água). Os biofertilizantes receberam ingredientes inorgânicos e foi incorporado esterco de galinha ao solo. As características avaliadas responderam às doses do BMV linearmente. Houve decréscimo da massa verde (GM) de plantas, de 1,43 a $0,88 \mathrm{~kg} / \mathrm{m}^{2}$, que é o produto comercial, e da altura de planta em 31,33 a 24,02 cm, atribuídos à adstringência conferida pela $M u s a$ sp. ao biofertilizante, junto com escassez de N. A massa seca da parte aérea (DM) incrementou de 11,29 a 13,75 g/100 g devido às hastes mais fibrosas sob carência de N. Os teores dos nutrientes aumentaram (B e Zn), não variaram $(\mathrm{N}, \mathrm{S}$ e $\mathrm{Cu})$ ou decresceram $(\mathrm{P}, \mathrm{K}, \mathrm{Ca}$, $\mathrm{Mg}, \mathrm{Fe}$ e $\mathrm{Mn}$ ) e os acúmulos incrementaram (N, S, K, B, Zn e Cu), decresceram ( $\mathrm{Fe}$ ) ou não se alteraram $(\mathrm{P}, \mathrm{Ca}, \mathrm{Mg}$ e $\mathrm{Mn}$ ). A análise de componentes principais evidenciou a DM e os acúmulos de $\mathrm{P}, \mathrm{K}$, $\mathrm{Ca}, \mathrm{Mg}$ e $\mathrm{S}$ com o mesmo sentido, além de antagonismo do $\mathrm{N}$ com o $\mathrm{Ca}$ e o $\mathrm{Mg}$, atribuído à perda de $\mathrm{N}$ em $\mathrm{pH}$ alcalino, pelo fosfato natural no BMV. A DM e os acúmulos de B, Cu e Zn aumentaram concomitante ao passo que os acúmulos de Fe e de Mn não competiram. O biofertilizante de esterco superou o BMV em GM (1,38 e $1,21 \mathrm{~kg} / \mathrm{m}^{2}$, respectivamente), assim como, nos acúmulos de $\mathrm{N}$ e $\mathrm{K}$.

Palavras-chave: Coriandrum sativum, adubação orgânica, fertilizante alternativo.

\section{Received on September 19, 2016; accepted on April, 7, 2017}

$\mathrm{C}$ Toriander (Coriandrum sativum, Apiaceae) originates from the territories of the Mediterranean Basin. In Brazil, this herb was introduced at the beginning of colonization (Melo et al., 2009), having great socioeconomic importance, especially in the Northern and Northeastern regions. The green mass of the leaves is used in natura as a condiment. The dry fruits, besides being used as condiments, are used in pharmaceutical and cosmetics industries (Daflon et al., 2014). The plant is a good source of calcium, iron, vitamin $\mathrm{C}$ and pro-vitamin A (Melo et al., 2009). In addition, it is a host of predators which control populations of phytophagous pests of vegetables (Resende et al., 2012).

Coriander is not a demanding plant in relation to soil and it is tolerant to acidity; however, the herb responds to organic and mineral fertilization (Filgueira, 2008). At the end of the crop cycle, leafy vegetable nutritional requirement becomes more intense, since, in the beginning of the cycle, the dry matter accumulation is slow. In soils with optimum artificial levels of fertility, macronutrients accumulation 
rates in coriander were from 30 to 35 days after sowing, with total extraction up to 40 DAS (descending order: $\mathrm{K}, \mathrm{Ca}$, $\mathrm{N}, \mathrm{Mg}$ and $\mathrm{P}$ ), higher $\mathrm{K}$ accumulation and lower accumulation of $\mathrm{P}$ (Grangeiro et al., 2011). In hydroponic cultivation, the macronutrient extraction by the coriander vegetative parts represented $85 \%(\mathrm{~N}) ; 79.9 \%(\mathrm{P}), 89.2 \%(\mathrm{~K})$; $86.4 \%(\mathrm{Ca}) ; 77.8 \%(\mathrm{Mg})$ and $82.3 \%$ (S), in relation to total (Donegá, 2009). Identically, the authors verified that total accumulation of micronutrients by coriander at 30 days after emergency in seedbeds, following the order: $\mathrm{Fe}, \mathrm{Zn}$, $\mathrm{Mn}, \mathrm{B}$ and $\mathrm{Cu}$, which corresponded to $18.402 ; 0.876 ; 0.816 ; 0.55$ and $0.141 \mathrm{mg} /$ plant (Haag et al., 1988). Given the above, an adequate supply of these nutrients is necessary, in any different coriander production system, in order to avoid nutritional deficiencies. Especially, the N supply, which is of decisive importance for growth and development of herbaceous vegetables (Filgueira, 2008; Echer et al., 2012), being the second most accumulated nutrient (Haag et al., 1988), besides, its deficiency affects the uptake of $\mathrm{P}$, $\mathrm{K}, \mathrm{Ca}$ and $\mathrm{Mg}$ (Araújo et al., 2016), among others.

In leafy vegetables, limiting nutrients are conventionally supplied through the application of mineral fertilizers and organic residues, in planting and top dressing application of $\mathrm{N}$. Thus, the coriander grown using poultry manure and NPK produced more green mass than the cultivation without these fertilizers (Santos, 2009). However, agroecological approaches recommend reducing and rationalizing the use of synthetic inputs, so that the organic fertilizers are likely to become of central importance to soil. Animal manures are good suppliers of $\mathrm{N}, \mathrm{P}$ and $\mathrm{K}$ (Bergo et al., 2005) and used in vegetables even in organic production system, in which also, some mineral sources can be applied, through compost or biofertilizer.

Biofertilizers result from the fermentation of manures, which can be enriched with other organic residues and mineral components, in water, under anaerobic or aerobic process (Souza \& Alcântara, 2007). They also result from exclusive digestion of organic material, with or without minerals (Bergo et al., 2005; Medeiros et al., 2007), being possible to use several organic residues. Banana industry waste is a potential substrate for anaerobic digestion processes (Souza et al., 2010), for its important content of K (Moreira \& Fageria, 2009), as well as, water hyacinths and aquatic plants (Guazelli et al., 2012), since they are free of water contaminants. Otherwise, $\mathrm{N}$ content will increase if $\mathrm{N}$-rich species are used (Souza \& Resende, 2003), such as leguminous plants.

Biofertilizers are supposed to have multiple effects; even if they do not own a standard formula. Coriander production was benefited by using a biofertilizer formulated, on a volume basis, with $50 \%$ of cattle manure and $50 \%$ of water (Silva et al., 2007). However, the biofertilizer prepared with plant residues could be a safer option for leafy vegetables, following Good Agricultural Practices (GAPs) criteria. Thus, this work aimed to evaluate the effect of a biofertilizer formulated with plant material and enriched with mineral sources on growth, production and acquisition of nutrients in coriander.

\section{MATERIAL AND METHODS}

The experiment was carried out from July 17 to August 27, 2013, in a greenhouse, chapel type, with open sides, covered with $150 \mu \mathrm{m}$-thick polyethylene film of low density, at Experimental Station of Embrapa Amazonia Oriental, Iranduba, Amazonas State, Brazil ( $3^{\circ} 15^{\prime} 13^{\prime \prime} \mathrm{S}$; $60^{\circ} 13^{\prime} 36^{\prime \prime} \mathrm{W}$; altitude $51 \mathrm{~m}$ ). The soil is classified as Yellow Argissol, with medium texture, showing signs of indigenous anthropogenic action, presenting the following chemical attributes $(0-20 \mathrm{~cm})$ : $\mathrm{pH}=5.2 ; \mathrm{Al}=0.0 ; \mathrm{MO}=22.0 \mathrm{~g} / \mathrm{kg} ; \mathrm{P}=48$ $\mathrm{mg} / \mathrm{dm}^{3} ; \mathrm{K}=26 \mathrm{mg} / \mathrm{dm}^{3} ; \mathrm{Ca}=1.9 \mathrm{cmol} /$ $\mathrm{dm}^{3} ; \mathrm{Mg}=1.0 \mathrm{cmol}_{\mathrm{c}} / \mathrm{dm}^{3}$ and $\mathrm{V} \%=36.4$.

The main treatments were doses of a biofertilizer prepared with plant materials (BMV): $0 \%, 5 \%, 10 \%$, $15 \%$ and $30 \%$ in water, besides an additional treatment with bovine manure biofertilizer (BEB), $10 \%$ in water. The experimental design was of randomized blocks, with six replicates. Each plot consisted of five double rows $(10 \mathrm{~cm}$ among them) of coriander cultivar Verdão, as direct sowing was carried out in beds (15 cm high and $1.2 \mathrm{~m}$ wide), being a row on each side of the drip tape $(0.25 \mathrm{~m}$ among them). The three central double rows $(1 \mathrm{~m})$ were the useful area $\left(0.75 \mathrm{~m}^{2}\right)$. As a basis, the planting beds received $1.5 \mathrm{~kg} / \mathrm{m}^{2}$ of poultry manure $[(\mathrm{g} / \mathrm{kg})=\mathrm{N}(31.0) ; \mathrm{P}(19.1) ; \mathrm{K}(25.0) ;$ $\mathrm{Ca}$ (26.0); $\mathrm{Mg}$ (6.2); S (5.9); and (mg/ $\mathrm{kg})=\mathrm{B}$ (44.2); $\mathrm{Cu}$ (67.3); Fe (1024.5); Mn (332.6); Zn (533.0)].

BMV was produced from parts of the species Flemingia macrophylla, Musa sp. and Azolla sp., using herbaceous branches and leaves; only leaves and leaves and roots, respectively. These parts were crushed and, then mixed in the following volumetric ratios: 40, 60 and $20 \mathrm{~L}$, respectively. This material was put in a 310-liter polyethylene tank, and then added $160 \mathrm{~L}$ of well water, Arad natural phosphate (FN) $\left[(2.8 \mathrm{~kg}) ; \mathrm{P}_{2} \mathrm{O}_{5}=\right.$ $33 \%$; $\mathrm{Ca}=37 \%$ and $\mathrm{S}=1 \%$; potassium sulfate (1.4 kg); magnesium sulfate (700 $\mathrm{g})$ and micronutrients, in the form of fritted trace elements (FTE) $[(280 \mathrm{~g}) \mathrm{S}=$ $3.2 \% ; \mathrm{B}=1.8 \% ; \mathrm{Cu}=0.8 \% ; \mathrm{Mn}=2 \%$; $\mathrm{Mo}=0.1 \%$ and $\mathrm{Zn}=9 \%$ ]; borax $(140 \mathrm{~g})$ and zinc sulfate $(70 \mathrm{~g})$; soluble content in the neutral ammonium citrate (CNA) + water (1:1): $\mathrm{Cu}(0.48 \%)$; $\mathrm{Mn}(1.2 \%)$; soluble content of citric acid (2\%) of: B (1.09\%); Mo (0.06\%) and Zn (5.4\%). In $\mathrm{BEB}$, the mixture of fresh manure and well water $(\mathrm{v} / \mathrm{v}=1 / 1)$ was also put in a 310-liter polyethylene tank; and the same nutrient sources and amounts were added proportionally to its volume.

Both biofertilizers resulted from anaerobic fermentation. Into BMV, there was addition of cow milk (5 L) with natural yogurt (110 g) and 1.0 $\mathrm{kg}$ of sugar (Bergo et al., 2005), to supply microorganisms. This was not applied to BEB due to the microbial population which is ordinary in ruminants (Guazelli et al., 2012). At 30 days, these biofertilizers were sampled, by a register at the bottom of the tank, in order to analyze the liquid part, resulting in the following composition of the plant material and the bovine manure biofertillizers, respectively 
$[(\mathrm{mL} / \mathrm{L}): \quad \mathrm{P}=0.11$ and $4.21 ; \mathrm{K}=0.52$ and 2.32; $\mathrm{Ca}=0.40$ and $4.18 ; \mathrm{Mg}=$ 0.75 and 1.98 and $S=0.09$ and 0.11 ; $(\mu \mathrm{L} / \mathrm{L}): \mathrm{Cu}=1.0$ and $10.50 ; \mathrm{Fe}=66.50$ and 823.0; $\mathrm{Mn}=70.0$ and 202.50 and $\mathrm{Zn}=97.0$ and 275.73]. The sieved biofertilizers (1 $\mathrm{mm}$ mesh) and diluted in water, according to the treatments, were applied manually $(1.5 \mathrm{~L} / \mathrm{m})$ among the double rows $(6.0 \mathrm{~L} / \mathrm{plot})$, weekly, totalizing four applications. Irrigation, with drip emitters, spaced every $10 \mathrm{~cm}$ from the drip tape, with a flow rate of $10.6 \mathrm{~L} / \mathrm{h} /$ meter, was monitored by using sensor Irrigas $\AA$. Weeding was carried out with the use of hoe, when necessary. No phytosanitary damage was noticed in plants.

Harvest was carried out at 40 days after sowing. Next traits were evaluated: the green mass of the whole harvested plants per plot (the roots were washed in order to remove the soil particles); plant height (average of three random measurements of plant packs, using a milimetric ruler, from the base of the plant up to the apex); aerial part dry mass [average between two plant packs (100 g each, without the roots) per plot, which were put in a greenhouse $\left(65^{\circ} \mathrm{C}\right)$, in paper bags, until constant mass]. Afterwards, the contents of macronutrient and micronutrient were determined and calculated the accumulation per $100 \mathrm{~g}$ of aerial part green mass (GMap) too (g/100 g of GMap; mg/100 g of GMap, respectively).

The obtained data were submitted to analyses of variance ( $\mathrm{F}$ test) and regression, besides contrasts with additional treatment ( $\mathrm{F}$ test), using the program IRRISTAT 5.0. Also the main components analysis was applied with aerial part dry mass and nutrient accumulation, for the main treatments, using the Facto Mine R package (Lê et al., 2008) for R v.3.2.1 (R Foundation for Statistical Computing, 2015).

\section{RESULTS AND DISCUSSION}

\section{Green mass, dry mass and plant height}

The green mass of the plants (GM) decreased linearly with the growing doses of the biofertilizer (BMV) (Figure

Table 1. Regression equations of contents and accumulations of macro and micronutrients in the coriander's aerial part with doses of biofertilizer prepared with a mix of plants. Manaus, Embrapa Amazônia Ocidental, 2013.

\begin{tabular}{|c|c|c|c|}
\hline Nutrient & $\begin{array}{l}\text { Regression equations of macronutrient contents } \\
\qquad(\mathrm{g} / \mathrm{kg})\end{array}$ & $\begin{array}{c}\text { Amplitude } \\
(0 \% \leftrightarrow 30 \%)(\mathrm{g} / \mathrm{kg})\end{array}$ & $\begin{array}{c}\text { Reference values }{ }^{1,2} \\
(\mathrm{~g} / \mathrm{kg})\end{array}$ \\
\hline $\mathrm{N} ; \mathrm{S}$ & $\overline{\mathrm{y}}=21.74 ; 1.34$ & - & 31.8 and $57.2 ; 1.5$ and 2.49 \\
\hline $\mathrm{P}$ & $y=5.08-0.0187^{\Delta} \times R^{2}=0.40$ & $5.08 \leftrightarrow 4.52$ & 2.0 and 5.59 \\
\hline K & $\mathrm{y}=57.72-0.1755^{* *} \times \mathrm{R}^{2}=0.88$ & $57.72 \leftrightarrow 52.46$ & 46.0 and 49.4 \\
\hline $\mathrm{Ca}$ & $y=13.56-0.0729 \mathbf{A}^{\mathbf{x}} \mathrm{R}^{2}=0.58$ & $13.56 \leftrightarrow 11.37$ & 5.4 and absent \\
\hline \multirow[t]{2}{*}{$\mathrm{Mg}$} & $\mathrm{y}=3.99-0.0216^{* *} \times \mathrm{R}^{2}=0.77$ & $3.99 \leftrightarrow 3.35$ & 3.6 and 2.36 \\
\hline & Macronutrient accumulations (g/100g of GMap) & & \\
\hline $\mathrm{N}$ & $\mathrm{y}=0.234+0.0027^{* *} \times \mathrm{R}^{2}=0.98$ & $0.234 \leftrightarrow 0.3251$ & - \\
\hline $\mathrm{P} ; \mathrm{Ca} ; \mathrm{Mg}$ & $\bar{y}=0.059 ; 0.155 ; 0.046$ & - & - \\
\hline $\mathrm{K}$ & $\mathrm{y}=0.651+0.0023^{* *} \times \mathrm{R}^{2}=0.72$ & $0.651 \leftrightarrow 0.7204$ & - \\
\hline \multirow[t]{2}{*}{$\mathrm{S}$} & $\mathrm{y}=0.015+0.0001^{* *} \times \mathrm{R}^{2}=0.72$ & $0.015 \leftrightarrow 0.018$ & - \\
\hline & Micronutrient contents (mg/kg) & $(\mathrm{mg} / \mathrm{kg})$ & $(\mathrm{mg} / \mathrm{kg})$ \\
\hline B & $\mathrm{y}=14.739+7.335^{* *} \mathrm{xR}^{2}=0.98$ & $14.739 \leftrightarrow 234.79$ & 39.0 \\
\hline $\mathrm{Zn}$ & $y=36.084+0.2339^{*} \times R^{2}=0.77$ & $36.084 \leftrightarrow 43.19$ & 63.3 \\
\hline $\mathrm{Cu}$ & $\overline{\mathrm{y}}=9.495$ & - & 10.3 \\
\hline $\mathrm{Fe}$ & $y=866.57-12.735^{*} \times R^{2}=0.96$ & $866.57 \leftrightarrow 484.52$ & 1347.5 \\
\hline \multirow[t]{2}{*}{$\mathrm{Mn}$} & $\mathrm{y}=61,324-0,6839^{* *} \mathrm{xR}^{2}=0,96$ & $61.324 \leftrightarrow 40.81$ & 61.8 \\
\hline & Micronutrient accumulations (mg/100g of GMap) & & \\
\hline B & $\mathrm{y}=0.095+0.1028^{* *} \mathrm{xR}^{2}=0.96$ & $0,095 \leftrightarrow 3,18$ & - \\
\hline $\mathrm{Zn}$ & $\mathrm{y}=0.405+0.0061^{* *} \mathrm{xR}^{2}=0.94$ & $0.405 \leftrightarrow 0.5881$ & - \\
\hline $\mathrm{Cu}$ & $\mathrm{y}=0.107+0.0008^{*} \times \mathrm{R}^{2}=0.94$ & $0.107 \leftrightarrow 0.1308$ & - \\
\hline $\mathrm{Fe}$ & $y=9.754-0.0966^{\mathbf{\Delta}} \times R^{2}=0.85$ & $9.754 \leftrightarrow 6.8558$ & - \\
\hline $\mathrm{Mn}$ & $\overline{\mathrm{y}}=0.643$ & - & - \\
\hline
\end{tabular}

${ }^{* * * *,}, \mathbf{S}$ Significant by $\mathrm{F}$ test $(\mathrm{p}<0.01, \mathrm{p}<0.05$ and $\mathrm{p}<0.1$, respectively. Amplitude $(0 \% \leftrightarrow 30 \%)$ nutrient content or accumulation with neighboring doses at the interval $(0 \% \leftrightarrow 30 \%)$ using the respective regression equation; $\bar{y}=$ average; GMap= aerial part green mass. ${ }^{1}$ Macronutrients: Haag et al. (1988), in soil and Daflon et al. (2014), in nutrient solution, respectively; ${ }^{2}$ Micronutrients: Haag et al. (1988). 
1A). Probably, the roots were damaged, particularly, the finest roots affecting water absorption, besides nutrients, damaging the chain of reactions which culminate in the production of the green mass. Damage to the roots should be related to the astringent sap of banana leaves in the BMV, since Costa et al. (2014) state that this sap is an effective healing. Moreover, mass accumulation in leafy vegetables is positively influenced by water content and by $\mathrm{N}$ supply. Thus, the GM production ranged from $1070.8 \mathrm{~g} / \mathrm{plot}\left(1.43 \mathrm{~kg} / \mathrm{m}^{2}\right)$ to $658.75 \mathrm{~g} / \mathrm{plot}\left(0.88 \mathrm{~kg} / \mathrm{m}^{2}\right)$, according to the lowest to the highest dose, coherent with the gradual reduction of plant size, which also, in regular visual inspections, showed progressively paler green color. This change in color is due to the lack of $\mathrm{N}$, which is related to unfavorable interactions between BMV and the reactions of this nutrient in soil. Therefore, water stress and $\mathrm{N}$ deficiency determined the decreasing of GM.

Aerial part dry mass (DM) increased linearly (Figure 1B), ranging from $11.29 \mathrm{~g} / 100 \mathrm{~g}$ of GMap ( $0 \% \mathrm{BMV})$ to
$13.75 \mathrm{~g} / 100 \mathrm{~g}$ of GMap (30\%). DM may increase by the greater number of stems, to the detriment to leaf expansion. Also, N-deficient plants may show thin and fibrous stems, due to carbohydrates excess which could not be used in the synthesis of amino acids and other nitrogenous compounds (Taiz \& Zeiger, 2006).

Plant height $(\mathrm{PH})$ decreased with the doses (Figure 1C), as well as GM, ranging from $31.33 \mathrm{~cm}(0 \% \mathrm{BMV})$ to $24.02 \mathrm{~cm}(30 \%)$. Oliveira et al. (2002), using cattle manure and NPK

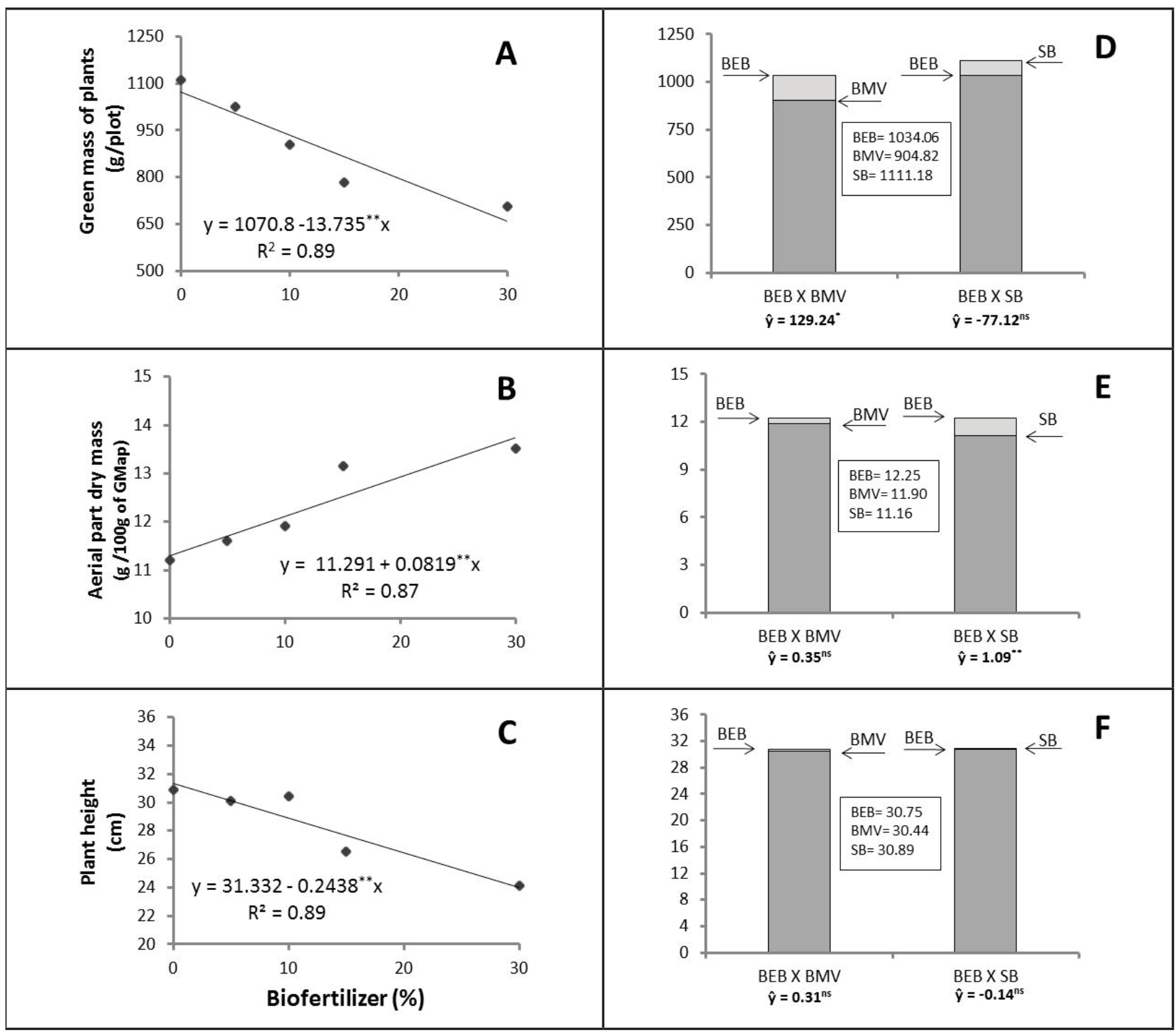

Figure 1. Green mass of plants (A), aerial part dry mass (B) and plant height (C) of coriander grown with BMV using different doses and contrasts $\mathrm{BEB}$ versus $\mathrm{BMV}$ and $\mathrm{BEB}$ versus $\mathrm{SB}$, respectively $(\mathrm{D}, \mathrm{E}$ and $\mathrm{F})$. BMV=biofertilizer prepared with vegetal material; $\mathrm{BEB}=$ bovine manure biofertilizer; $\mathrm{SB}=$ without biofertilizer, GMap= aerial part green mass. Useful area of the plot $\left(0.75 \mathrm{~m}^{2}\right)$. *;** significant by $\mathrm{F}$ test $(\mathrm{p}<0.05$ and $\mathrm{p}<0.01$, respectively $) ;{ }^{\text {ns }}=$ non-significant. 
obtained maximum $\mathrm{PH}, 35 \mathrm{~cm} . \mathrm{N}$ is the nutrient which most limits plant growth (Marschner, 2012), therefore its scarcity does not help PH and the same factors affected the responses for GM and PH.

Contrasts between treatments (BEB versus $B M V$ and $B E B$ versus $S B$ (bovine manure in the absence of biofertilizer) were studied for GM (Figure 1D), DM (Figure 1E) and PH (Figure 1F). BEB surpassed BMV for GM ( $\hat{y}=$ $\left.129.24^{*}\right)$ also SB for DM $\left(\hat{y}=1.09^{* *}\right)$, showing no significance for the other traits. BEB showed, in the liquid part, highest contents for all macronutrients, whereas, for the BMV were attributed effects related to root injury, to the detriment of water and nutrient uptake, as well as a low N. Thus, BEB was more effective in relation to GM yield, that is the commercial product. Alike, it is reasonable that the BEB provided conditions for greater production of DM than SB has.

Contents and nutrients accumulations in the plant's aerial part

BMV doses affected distinctly concentrations and accumulations of nutrients in the aerial part of coriander plant, with significant responses adjusting to different linear functions; thus, the amplitudes of their contents in DM were calculated, using the lowest and the highest dose of the interval studied $(0 \% \leftrightarrow 30 \%)$, in order to be compared to reference values (Table 1).

$\mathrm{N}$ contents did not range according to the doses, whereas accumulations increased linearly, which did not reflect in GM, possibly, because the increase $(0.0027 \mathrm{~g} / 100 \mathrm{~g}$ of GMap), per each unit applied to BMV, was little expressive. Nitrogen is fundamental to increase vegetative growth in leafy vegetables (Echer et al., 2012); therefore, there was $\mathrm{N}$ scarcity or depreciation on the acquisition of this nutrient. $\mathrm{S}$ also showed significance only for accumulation, which showed inexpressive linear increase $(0.0001 \mathrm{~g} / 100 \mathrm{~g}$ of GMap, per unit of BMV), concluding that the addition of sulphates ( $\mathrm{K}$ and $\mathrm{Mg}$ ) into BMV had little impact in acquisition of $\mathrm{S}$ by coriander. $\mathrm{SO}_{4}^{2-}$ is absorbed in low amounts and speed depends on the accompanying cation (Vitti et al., 2006): $\mathrm{Ca}^{2+}<\mathrm{Mg}^{2+}<\mathrm{NH}_{4}^{+}<\mathrm{K}^{+}$. In both cases,

Table 2. Treatment averages and contrasts estimates $(\hat{y})$ of biofertilizer of bovine manure (BEB) versus biofertilizer prepared with a mix of plants (BMV) and BEB versus without biofertilizer (SB) for contents and accumulations of macronutrients in the coriander's aerial part. Manaus, Embrapa Amazônia Ocidental, 2013.

\begin{tabular}{|c|c|c|c|c|c|}
\hline \multirow{2}{*}{ Macronutrients } & \multicolumn{3}{|c|}{ Averages } & \multicolumn{2}{|c|}{$\hat{\mathrm{Y}}$} \\
\hline & BEB & BMV & SB & BEB x BMV & BEB $\times$ SB \\
\hline & \multicolumn{5}{|c|}{ Contents (g/kg) } \\
\hline $\mathrm{N}$ & 20.71 & 21.89 & 21.60 & $-1.18^{\mathrm{ns}}$ & $-0.89^{\text {ns }}$ \\
\hline $\mathrm{P}$ & 5.12 & 5.34 & 4.84 & $-0.22^{\mathrm{ns}}$ & $0.28^{\mathrm{ns}}$ \\
\hline $\mathrm{K}$ & 55.41 & 57.14 & 57.12 & $-1.73^{*}$ & $-1.71^{*}$ \\
\hline $\mathrm{Ca}$ & 14.25 & 13.75 & 13.17 & $0.50^{\text {ns }}$ & $1.08^{\mathrm{ns}}$ \\
\hline $\mathrm{Mg}$ & 4.09 & 4.00 & 3.90 & $0.09^{\text {ns }}$ & $0.19^{\text {ns }}$ \\
\hline \multirow[t]{2}{*}{$\mathrm{S}$} & 1.31 & 1.48 & 1.33 & $-0.17^{*}$ & $0.02^{\text {ns }}$ \\
\hline & \multicolumn{5}{|c|}{ Accumulations (g/100 g of GMap) } \\
\hline $\mathrm{N}$ & 0.38 & 0.26 & 0.24 & $0.12^{* *}$ & $0.14^{* *}$ \\
\hline $\mathrm{P}$ & 0.055 & 0.064 & 0.054 & $-0.009^{*}$ & $0.0003^{\mathrm{ns}}$ \\
\hline $\mathrm{K}$ & 0.77 & 0.68 & 0.64 & $0.09^{* *}$ & $0.13^{* *}$ \\
\hline $\mathrm{Ca}$ & 0.10 & 0.16 & 0.15 & $-0.06^{* *}$ & $-0.04^{* *}$ \\
\hline $\mathrm{Mg}$ & 0.035 & 0.048 & 0.044 & $-0.013^{* *}$ & $-0.008^{*}$ \\
\hline S & 0.019 & 0.018 & 0.015 & $0.001^{\text {ns }}$ & $0.004 * *$ \\
\hline
\end{tabular}

**,* Significant by $\mathrm{F}$ test ( $\mathrm{p}<0.01$ and $\mathrm{p}<0.05$, respectively) and ${ }^{\mathrm{ns}}$ Non-significant; GMap= aerial part green mass. the average of contents was lower than the reference values (Haag et al., 1988; Daflon et al., 2014).

$\mathrm{P}$ contents decreased linearly with the doses and the accumulations were not responsive. P utilization is lower even with the application of the fertilizer (Araújo \& Machado, 2006). Damages to roots and precipitation of $\mathrm{Ca}^{++}$, as well as FN, under the highest doses of BMV, probably interfered with its acquisition. $\mathrm{K}$ contents also decreased linearly with doses; on the other hand, the accumulations increased linearly. By the angular coefficient of functions, respectively, the highest negative value for $\mathrm{K}$ contents $(0.1755)$ compared to the positive value of the accumulation (0.0023), shows a decrease of $\mathrm{K}$ in DM, by dilution. $\mathrm{P}$ was the least accumulated nutrient in coriander, whereas $\mathrm{K}$ was the most absorbed nutrient (Grangeiro et al., 2011); thus, compared to reference values in soil and nutrient solution, $\mathrm{P}$ contents were the most consistent with the nutrients obtained in nutrient solution, whereas $\mathrm{K}$ contents were higher in both conditions.

$\mathrm{Ca}$ and $\mathrm{Mg}$ contents decreased linearly with the doses and there was no significance for accumulations of these nutrients which was similar to P. In the irrigation water, phosphates are incompatible with $\mathrm{Ca}$ and $\mathrm{Mg}$ (Borges \& Silva, 2011) and FN added into $\mathrm{BMV}$, by its composition $(\mathrm{Ca}=$ $37 \% ; \mathrm{P}_{2} \mathrm{O}_{5}=33 \%$ ), may have affected the acquisition of these nutrients. Moreover, Ca delivered by FN may have decreased $\mathrm{Mg}$ absorption rate (Vitti et $a l ., 2006)$, which was practically a third of what was verified for $\mathrm{Ca}$. Under these conditions, $\mathrm{Ca}$ contents were more than double of those recorded by Haag et al. (1988), whereas Mg contents were close. Granjeiro et al. (2011) verified that $\mathrm{Ca}$ accumulation $(20.4 \mathrm{mg} / \mathrm{plant})$ practically double the $\mathrm{Mg}$ content (10.18 $\mathrm{mg}$ /plant).

The contrast between BEB versus BMV was significant only for contents of $\mathrm{K}$ and $\mathrm{S}\left(\hat{\mathrm{y}}=-1.73^{*} ;-0.17^{*}\right.$, respectively), being BMV superior (Table 2). For BEB $x \mathrm{SB}$, the significance occurred for the $\mathrm{K}$ content $(\hat{y}=-1.71 *)$, which was higher in SB; thus, this fact can be an effect of concentration since DM was higher than 
BEB, inversely, by diluting its content. Cattle manure shows considerable contents of $\mathrm{K}(23.5 \mathrm{~g} / \mathrm{kg})$, being able to raise the $\mathrm{K}^{+}$of the biofertilizer.

In relation to accumulations, the contrast $\mathrm{BEB}$ versus $\mathrm{BMV}$, with no significance for $\mathrm{S}$, indicated higher values of $\mathrm{N}$ and $\mathrm{K}$ in BEB, which is consistent with its greater production of GM (Figure 1D) and with invariable DM in this contrast (Figure 1E). On the other hand, the highest accumulations of $\mathrm{P}, \mathrm{Ca}$ and $\mathrm{Mg}$ in BMV may occur due to the fact that their organic acids decreased $P$ fixing (Benites et al., 2005), particularly, solubilizing the probable phosphates of $\mathrm{Ca}$. Moreover, synergism between $\mathrm{P}$ and $\mathrm{Mg}$ in the absorption (Silva \& Trevizam, 2015) may have increased both nutrients in the aerial part. In BEB $x$ SB, significance occurred for the accumulation of all the macronutrients, except for P. Greater accumulations of $\mathrm{N}, \mathrm{K}$ and $\mathrm{S}$ were observed with BEB, and of $\mathrm{Ca}$ and $\mathrm{Mg}$ with SB. The highest accumulation of $\mathrm{Ca}$ and $\mathrm{Mg}$ in $\mathrm{SB}$ may indicate undesirable effect of BEB on its acquisition, and this may be related to the effect of the triad $\mathrm{P}, \mathrm{Ca}$ and $\mathrm{Mg}$.

The increasing doses of BMV increased linearly the contents of
$\mathrm{B}$ and $\mathrm{Zn}$ and their accumulations. B uptake can be excessive when its content in the solution is high (Dechen \& Nachtigall, 2006), and it is verified, from the $10 \%$ dose, that the contents reach higher values than the comparison references, considering the marked angular coefficient of the function $(+7.335)$. However, in the amplitude of $\mathrm{Zn}$ contribution, the values were lower than the reference used. For $\mathrm{Zn}$, values lower than $25.0 \mathrm{mg} / \mathrm{kg}$ are considered deficient.

$\mathrm{Cu}$ contents did not change with the doses of BMV, whereas contents of Fe and Mn decreased linearly. Mn accumulation was not affected either, $\mathrm{Cu}$ accumulation has increased and $\mathrm{Fe}$ accumulation has decreased linearly. The average contents of $\mathrm{Cu}$ and the relative amplitude of $\mathrm{Fe}$ were lower than the reference values. Mn referential values were the same; however, only without the biofertilizer $(0 \%)$, decreased with an increase of doses. Despite appreciable supply of Fe by the soil with manure, BMV decreased the acquisition of $\mathrm{Fe}$, probably, due to changes in $\mathrm{pH}$ and concentrations of $\mathrm{P}$ and $\mathrm{Ca}$ (Luchini, 2008), which interfere with the acquisition of this

Table 3. Treatment averages and contrast estimates $(\hat{y})$ biofertilizer of bovine manure (BEB) versus biofertilizer produced with a mix of plants (BMV) and BEB versus without biofertilizer (SB) for contents and accumulations of micronutrients in the coriander's aerial part. Manaus, Embrapa Amazônia Ocidental, 2013.

\begin{tabular}{lcccccc}
\hline \multirow{2}{*}{ Micronutrients } & \multicolumn{3}{c}{ Averages } & & \multicolumn{2}{c}{$\hat{Y}$} \\
\cline { 2 - 4 } \cline { 6 - 7 } & BEB & BMV & SB & & BEB x BMV & BEB x SB \\
\hline $\mathrm{B}$ & 75.88 & 72.44 & 32.59 & & $3.44^{\text {ns }}$ & $43.29^{\text {ns }}$ \\
$\mathrm{Zn}$ & 38.69 & 40.66 & 34.40 & & $-1.97^{\text {ns }}$ & $4.29^{\text {ns }}$ \\
$\mathrm{Cu}$ & 9.11 & 9.94 & 9.56 & & $-0.83^{\text {ns }}$ & $-0.45^{\text {ns }}$ \\
$\mathrm{Fe}$ & 415.29 & 694.05 & 891.35 & & $-278.76^{* *}$ & $-476.06^{* *}$ \\
$\mathrm{Mn}$ & 55.04 & 56.58 & 61.03 & $-1.54^{\text {ns }}$ & $-5.99^{\text {ns }}$ \\
\hline & \multicolumn{5}{c}{ Accumulations $\mathbf{( m g / 1 0 0 ~ g ~ o f ~ G M a p ) ~}$} \\
\hline $\mathrm{B}$ & 2.839 & 0.863 & 0.365 & $1.980^{* *}$ & $2.470^{* *}$ \\
$\mathrm{Zn}$ & 0.451 & 0.483 & 0.385 & & $-0.032^{\text {ns }}$ & $0.066^{\text {ns }}$ \\
$\mathrm{Cu}$ & 0.109 & 0.118 & 0.107 & & $-0.009^{\text {ns }}$ & $0.002^{\text {ns }}$ \\
$\mathrm{Fe}$ & 4.027 & 8.220 & 9.764 & & $-4.190^{* *}$ & $-5.740^{* *}$ \\
$\mathrm{Mn}$ & 0.554 & 0.669 & 0.671 & & $-0.115^{\text {ns }}$ & $-0.117^{\text {ns }}$ \\
\hline
\end{tabular}

${ }^{* * * *}$ Significant by $\mathrm{F}$ test ( $\mathrm{p}<0,01$ and $\mathrm{p}<0,05$, respectively) and ${ }^{\mathrm{ns}}$ Non-significant; GMap= aerial part green mass. nutrient. Since Mn was added into the effluent, an increase in contents proportionally to the doses would be expected. However, its absorption is basically controlled metabolically (Dechen \& Nachtigall, 2006) and Mn extraction by the coriander is lower than Fe extraction (Haag et al., 1988).

The contrasts BEB versus BMV and BEB versus SB (with no biofertilizer) were studied for contents and accumulations of micronutrients (Table 3). For the contrast BEB versus $\mathrm{BMV}$, significance was only noticed for Fe contents $(\hat{y}=-278.76 \mathrm{mg} / \mathrm{kg})$, with superiority of BMV. On the contrast $\mathrm{BEB}$ versus $\mathrm{SB}$, a significance was noticed only for Fe contents, with superiority of SB $(\hat{y}=-476.06 \mathrm{mg} / \mathrm{kg})$. In both situations, BEB was less impactful for Fe content, which accumulation stood out in BMV and in SB. Fe acquisition in plants is affected by the $\mathrm{pH}$, concentration of $\mathrm{Ca}$ and $\mathrm{P}$; balance $\mathrm{Fe} / \mathrm{Mn}$, among others (Dechen \& Nachtigall, 2006). The contents of $\mathrm{Ca}$ and $\mathrm{P}$ in the liquid part of BEB were more accentuated, and Fe shows affinity to form phosphate binders and the slower speed of $\mathrm{Fe} 3+$ reduction at higher $\mathrm{pH}$, phenomena which reduce the supply to the roots. In both contrasts, significance also occurred for B, considering that BEB surpassed BMV and SB. In the first, probably, due to the increased movement of $\mathrm{B}$ with transpiration flow, since BEB yielded more GM than BMV (Figure 1D). And due to the fact that BEB surpassed SB, the lowest yield of DM in SB (Figure 1E) can be emphasized, because it was verified that the accumulation of $B$ followed the increase of DM.

\section{Principal components analysis}

The results of the principal components analysis (PCA), applied into DM correlation matrix (g/100 g of GMap) and macronutrient accumulations (g/100 $\mathrm{g}$ of GMap), demonstrated that, in the correlation circle, the first two axes explained $76.30 \%$ of total variability, being $48.91 \%$ in axis 1 and $27.39 \%$ in axis 2 (Figure 2). The principal component 1 (PC1), with distribution in axis 1 , was influenced by dry mass of the aerial part (MS), $\mathrm{P}, \mathrm{K}, \mathrm{Ca}, \mathrm{Mg}$ and $\mathrm{S}$, all with positive eigenvectors 


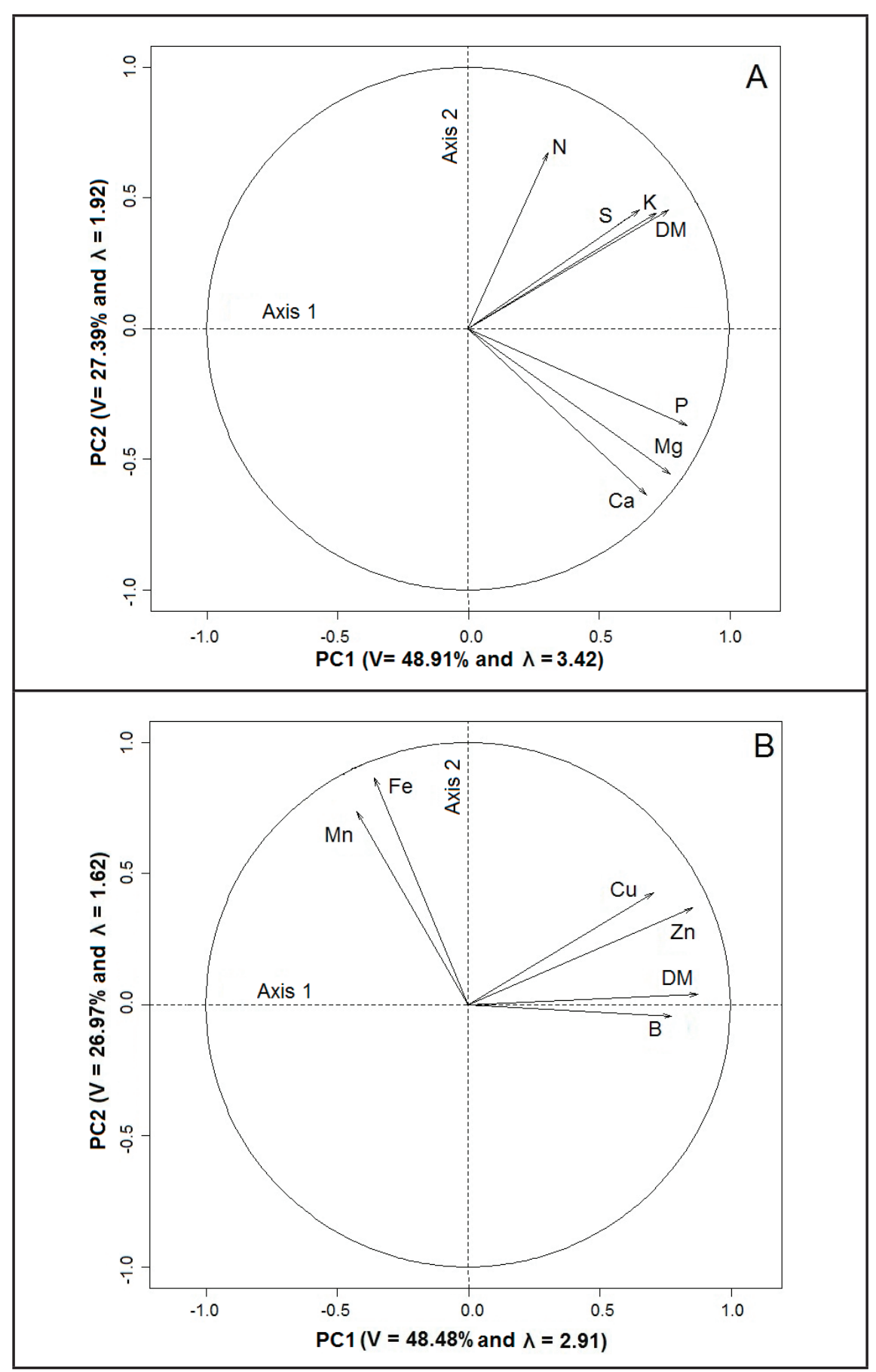

Figure 2. Correlation circle between accumulations of macro (A) and micronutrients (B) and aerial part dry mass (DM) of the coriander in two first principal components (PC1 and PC2). Variance (V) and eingenvalues of correlation matrix ( $\lambda$ ). Manaus, Embrapa Amazônia Ocidental, 2013.

$(0.725 ; 0.841 ; 0.770 ; 0.685 ; 0.775$ and 0.658 , respectively); therefore, the same occur with DM and with the acquisition of these macronutrients. $\mathrm{PC} 2$, in axis 2, demonstrates competition of $\mathrm{N}(0.674)$ with $\mathrm{Ca}(-0.636)$ and $\mathrm{Mg}(-0.556)$, by the opposite signals. Therefore, increasing $\mathrm{N}$ accumulation will decrease the accumulation of $\mathrm{Ca}$ and $\mathrm{Mg}$ and viceversa. This indicates losses of $\mathrm{N}$ through volatilization, which are favored, among other factors, by alkaline $\mathrm{pH}$. In this case, due to contribution of FN in the biofertilizer raising the $\mathrm{pH}$ (Luchini, 2008), besides adding more $\mathrm{Ca}$ and $\mathrm{Mg}$ to the soil.
Evaluating PCA, which was applied to DM correlation matrix (100 g of GMap) and micronutrient accumulations (mg/100 $\mathrm{g}$ of GMap), it is possible to verify that, in the correlation circle, the first two axes explained $75.45 \%$ of total variance of the original traits, being $48.48 \%$ in axis 1 and $26.97 \%$ in axis 2 (Figure 2 ). PC1, in axis 1, represents DM (0.876) and the accumulations of $\mathrm{B}$ (0.776), $\mathrm{Cu}(0.710)$ and $\mathrm{Zn}(0.857)$, by the largest coefficients of the same signal, indicating that DM and the acquisition of these micronutrients increased concomitantly. In PC2, axis 2 , it is easily verified that accumulations of $\mathrm{Fe}(0.867)$ and $\mathrm{Mn}$ (0.738), with positive eigenvectors, do not express competition. In general, $\mathrm{PC} 1$ can better explain the data; however, PC2 was additional on these metal micronutrients, which is important since $\mathrm{Mn}$, and not $\mathrm{Fe}$, was added into the biofertilizer.

In short, the increase of BMV concentrations ( $\%$, in water) led a decrease in green mass yield of the coriander, which is a product with commercial value, as well as the plant height; however, the aerial part dry mass increased. On the other hand, the total amounts of nutrients in the aerial part of plants increased (N, S and K; B, Zn and $\mathrm{Cu})$, decreased $(\mathrm{Fe})$ or no responsed $(\mathrm{P}$, $\mathrm{Ca}$ and $\mathrm{Mg} ; \mathrm{Mn}$ ). Interactions between $\mathrm{BMV}$ and $\mathrm{N}$ in soil, decreasing its availability, conditioned growth and production, since the results related to nutrients were not counterproductive. On the other hand, BEB surpassed BMV in relation to the green mass of the plants and to the accumulations of $\mathrm{N}$ and $\mathrm{K}$. In short, it is inferred that Musa sp and $\mathrm{FN}$ in the composition of BMV have compromised its efficacy.

\section{ACKNOWLEDGEMENTS}

To Foundation for Research Support of the State of the Amazon FAPEAM, for the financial support for this research.

\section{REFERENCES}

ARAÚJO, AP; MACHADO, CTT. 2006. X-Fósforo. In: FERNANDES, MS (ed) 
Nutrição mineral de plantas. Viçosa: SBCS. p.253-280.

ARAUJO, KP; FAQUIN, V; BALIZA, DP; ÁVILA, FW; GUERRERO, AC. 2016. Crescimento e nutrição mineral de cebolinha verde cultivada hidroponicamente sob diferentes concentrações N,P,K. Revista Ceres, 63: 232-240. Disponível em: http:// www.scielo.br/pdf/rceres/v63n2/2177-3491rceres-63-02-00232.pdf Acessado em 20 de outubro de 2016.

BENITES, VM; MADARI, B; BERNARDI, ACC; MACHADO, PLOA. 2005. Matéria orgânica. In: WADT, PGS (ed). Manejo do solo e recomendação de adubação para o Estado do Acre. Rio Branco: Embrapa Acre. p.93-120.

BERGO, CL; RICCI, MSF; ROSÁRIO, AAS; BRAGA, RR. 2005. Adubação orgânica. In: WADT, PGS (ed) Manejo do solo e recomendação de adubação para o Estado do Acre. Rio Branco: Embrapa Acre. p.325-348.

BORGES, AL; SILVA, DJ. 2011. Fertilizantes para irrigação. In: SOUSA, VF; MAROUELLI, WA; COELHO, EF; PINTO, JM; COELHO FILHO, MA. Irrigação e fertirrigação em fruteiras e hortaliças. Brasília: Embrapa Informação Tecnológica. p.254-264.

COSTA, A; PRESTES, G; SOUTO, LiM; MARIOT, EJ. 2014. Análise da eficácia da seiva da bananeira e iodo polividona em ferimentos de coelho. In: MOSTRA NACIONAL DE INICIAÇÃO CIENTIIFICAE INTERDISCIPLINAR, 7. Anais eletrônicos... Araquari-SC: IFC. 5p. Disponível em: http:// ocs.araquari.ifc.edu.br/index.php/micti/ micti2014/paper/download/370/127. Acessado em 25 de fevereiro, 2014.
DAFLON, DSG; FREITAS, MSM; CARVALHO, AJC; MONNERAT, PH; PRINS, CL. 2014. Sintomas visuais de deficiência de macronutrientes e boro em coentro. Horticultura Brasileira 32: 28-33.

DECHEN, AR; NACHTIGALL, GR. 2006. Elementos essenciais e benéficos às plantas superiores. In: FERNANDES, MS (ed) Nutrição mineral de plantas. Viçosa: SBCS. p.1-5.

TOS, CS; ARAUJO, JS; NASCIMENTO, JT. 2002. Produção de coentro cultivado com esterco bovino e adubação mineral. Horticultura Brasileira 20: 477-479.

R FOUNDATION FOR STATISTICAL COMPUTING. 2015. $R$ : a language and environment for statistical computing. Disponível em http://cran.r-project.org/ manuals.html. Acessado em 09 de julho de 2015.

RESENDE, ALS; HARO, MM; SILVA, VF; SOUZA, B; SILVEIRA, LCP. 2012. Diversidade de predadores em coentro, endro e funcho sob manejo orgânico. Arquivos do Instituto Biológico 79: 193-199.

SANTOS, KP. 2009. Desempenho agronômico do coentro submetido a diferentes adubações. Altamira: UFPA. 51p (Monografia graduação). Disponível em: http://www.aba-agroecologia. org.br/revistas/index.php/cad/article/ viewFile/2713/2361 Acessado em 18 de outubro de 2016.

SILVA, AF; CCOELHO, AIA; RAMOS, JB; SANTANA, LM; FRANÇA, CRRS. 2007. Características químicas e aceitação de biofertilizante preparado e utilizado em horta agroecológica do Semi-Árido Nordestino.
Revista Brasileira de Agroecologia 2: 962-965. Disponível em:http://www.abaagroecologia.org.br/revistas/index.php/cad/ article/viewFile/2713/2361. Acessado em 19 de outubro de 2016.

SILVA, MLS; TREVIZAM, AR. 2015. Interações iônicas e seus efeitos na nutrição das plantas. Informações agronômicas, 49, 16p. Disponível em: http://www.ipni.net/publication/ia-brasil. nsf/0/8C2796BCB76E0F9B83257E2000656 0E2/\$FILE/Page10-16-149.pdf Acessado em 19 de outubro de 2016.

SOUZA JL; RESENDE, P. 2003. Manual de horticultura orgânica. Viçosa: Aprenda Fácil. $569 \mathrm{p}$.

SOUZA, RB; ALCÂNTARA, FA. 2007. Adubação orgânica. In: HENZ, GP; ALCÂNTARA, FA; RESENDE, FV. Produção orgânica de hortaliças: o produtor pergunta e a Embrapa responde. Brasília: Embrapa Informação Tecnológica. p.113-127. (Coleção 500 perguntas, 500 respostas).

SOUZA, O; FEDERIZZI, M; COELHO, B; WAGNER, TM; WISBECK, E. 2010. Biodegradação de resíduos lignocelulósicos gerados na bananicultura e sua valorização para a produção de biogás. Revista Brasileira de Engenharia Agrícola e Ambiental 14: 438-443.

TAIZ, L; ZEIGER, E. 2006. Fisiologia vegetal. 3. ed. Porto Alegre: Armed. 719p. 1a. reimpressão.

VITTI, GC; LIMA, E; CICARONE, F. 2006. XIICálcio, magnésio e enxofre. In: FERNANDES, MS (ed) Nutrição mineral de plantas. Viçosa: SBCS. p.299- 325. 